\title{
Advanced Placement Program News
}

\section{Teresa Sanchez-Lazer, Educational Testing Service}

The College Board's Advanced Placement Government and Politics program has grown rapidly since its debut in 1987, when examinations were administered to approximately 10,000 students. In June 1994, approximately 150 faculty consultants are expected to collaborate in the grading of more than 31,000 examinations.

AP examinations in United States Government and Politics and Comparative Government and Politics are developed and reviewed by a committee of college and high school faculty, in consultation with content and assessment specialists at Educational Testing Service. The 1993-94 development committee includes: Michael Mitchell, Arizona State University, Chair; Linda Driscoll, Falls Church High School (Virginia); Barbara McAdorey, Sachem High School (New York); E. Wally Miles, San Diego State University; Charles Hadley, University of New Orleans; and Jean Robinson, Indiana University.

Each AP Government and Politics Examination comprises a 45 minute multiple-choice section and a 75-minute, 2-part free-response (essay) section. The free-response sections of the examinations are graded by college and high school AP faculty consultants at an annual essay reading each June. The 1994 grading standards will be set by the chief faculty consultant, Harold Barger of Trinity University, in consultation with a group of college faculty consultants and ETS staff.

\section{Comparability Studies Under Way}

College comparability studies for the AP programs in United States Government and Politics and Comparative Government and Politics began in October 1993 and will continue through spring 1994. For the studies, college faculty who teach introductory United States or Comparative Government and Politics administered the 1994 Advanced Placement examinations in Government and Politics to their students. A sample of nearly 1,000 college students is anticipated for the United States Government and Politics examination; for Comparative Government and Politics, the sample will include about $500 \mathrm{col}-$ lege students. College students' responses to the free-response sections of the examinations will be re-graded at the annual essay reading in June 1994 to compare the college instructors' assessment of their own students' performance with the AP consultants' assessment of the same students.
Comparisons of the college students' overall performance on the examinations against that of the overall AP student population will help the committee maintain appropriate examination difficulty levels, and will assist the chief faculty consultant in setting cut scores for determining AP Government and Politics grades. A report on the results of the study will be available by early 1995 . Information on the performance of individual colleges will be made available to the participating faculty only, and will include a comparison of each college's participant group with that of the AP population and with all other college students participating in the study.

In fall 1994, the 1994 AP Government and Politics examinations with samples of a range of actual student responses and a discussion of the grading standards used in evaluating the free-response answers will be published.

\section{Additional AP Information}

For additional information on the AP Government and Politics programs, please contact: Claire Melican or Teresa Sanchez-Lazer, Educational Testing Service, Mailstop 27-E, Princeton, NJ 08541. Phone: (609) 921-9000. 